\title{
Energy Resources Program
}

\section{National Assessment of Carbon Dioxide Enhanced Oil Recovery and Associated Carbon Dioxide Retention Resources-Summary}

In 2020, the U.S. Geological Survey (USGS) completed a probabilistic assessment of the volume of technically recoverable oil resources that might be produced by using current carbon dioxide enhanced oil recovery $\left(\mathrm{CO}_{2}\right.$-EOR) technologies in amenable conventional oil reservoirs underlying the onshore and State waters areas of the conterminous United States. The assessment also includes estimates of the mass of $\mathrm{CO}_{2}$ that could be stored (retained) in the assessed oil reservoirs following the application of the $\mathrm{CO}_{2}$-EOR process. The USGS assessment team evaluated more than 3,500 oil reservoirs that were miscible to injected $\mathrm{CO}_{2}$. The assessed reservoirs are in 185 previously defined USGS plays in 33 petroleum provinces of 7 national regions. The team estimated that the total technically recoverable oil resulting from the application of the $\mathrm{CO}_{2}$-EOR process ranges from approximately
25,000 million barrels (MMbbl) at the $\mathrm{P}_{5}$ percentile to as much as $32,000 \mathrm{MMbbl}$ at the $\mathrm{P}_{95}$ percentile, with a mean of 29,000 MMbbl. The associated $\mathrm{CO}_{2}$ retention ranges from approximately 7,400 million metric tons (Mt) at the $\mathrm{P}_{5}$ percentile to as much as $9,500 \mathrm{Mt}$ at the $\mathrm{P}_{95}$ percentile, with a mean of $8,400 \mathrm{Mt}$. The results are summarized in this fact sheet (figs. $1 A, B, 2 A, B$; tables 1,2) and are provided in more detail in the companion data release and circular (Warwick and others, 2022a, b).

The West Texas and Eastern New Mexico region (primarily its Permian Basin) and the Gulf Coast region together contain 60 percent of the mean assessed $\mathrm{CO}_{2}$-EOR oil potential and 61 percent of the mean assessed $\mathrm{CO}_{2}$ retention (figs. $1 A, B, 2 A, B$ ). Other regions with significant resource potential include the Midcontinent region and the Rocky Mountains and Northern Great Plains region.
A. Oil that could be produced with $\mathrm{CO}_{2}-\mathrm{EOR}$

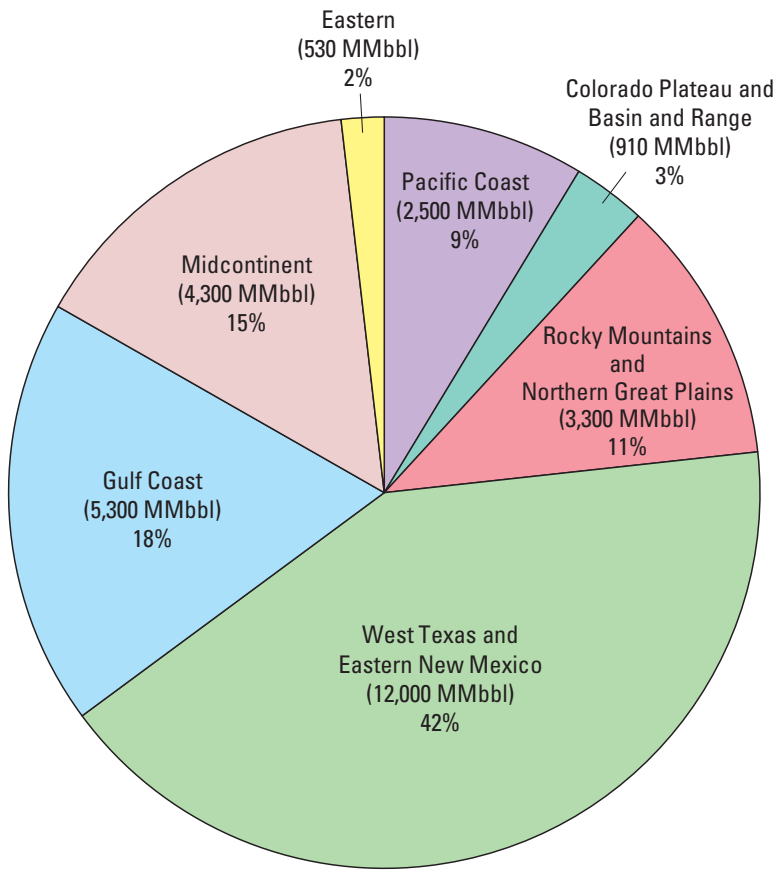

B. $\mathrm{CO}_{2}$ that could be retained with $\mathrm{CO}_{2}-\mathrm{EOR}$

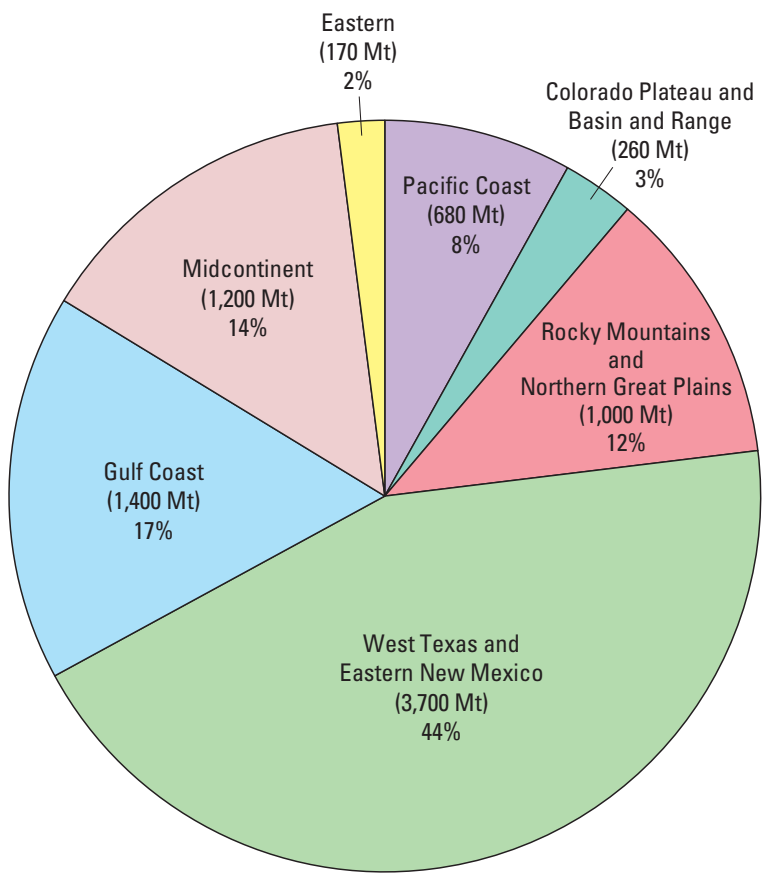

Figure 1. Pie charts showing regional mean estimates by the U.S. Geological Survey in 2020 of $(A)$ technically recoverable volumes of oil that could be produced with the application of the carbon dioxide enhanced oil recovery $\left(\mathrm{CO}_{2}\right.$-EOR) process and $(B)$ masses of subsurface carbon dioxide $\left(\mathrm{CO}_{2}\right)$ that could be stored (retained) with the application of the $\mathrm{CO}_{2}$-EOR process in existing miscible oil reservoirs underlying onshore and State waters areas of the conterminous United States. A mean total of 29,000 million barrels (MMbbl) of oil was estimated to be producible from reservoirs amenable to the $\mathrm{CO}_{2}$-EOR process. A mean total of 8,400 million metric tons (Mt) was estimated for subsurface $\mathrm{CO}_{2}$ retention associated with the application of the $\mathrm{CO}_{2}$-EOR process. Resources in Alaska, Hawaii, and federally owned offshore areas were not assessed. Mean values sum to totals but are reported to only two significant figures. Regional outlines are shown in figure 2. 
A. Oil that could be produced with $\mathrm{CO}_{2}-\mathrm{EOR}$

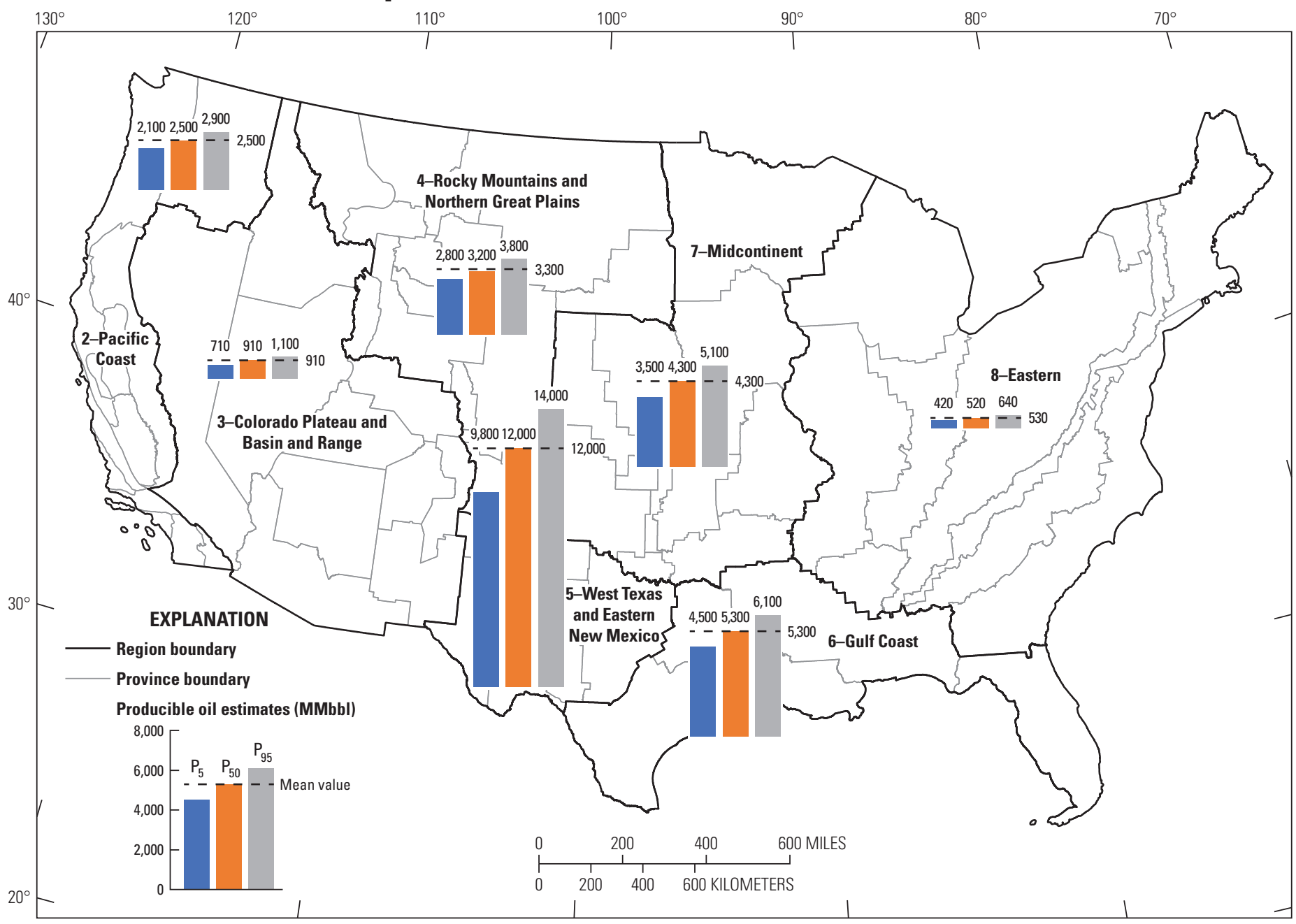

Figure 2. Maps of the conterminous United States and bar graphs showing regional estimates by the U.S. Geological Survey in 2020 of $(A)$ technically recoverable volumes of oil, in millions of petroleum barrels (MMbbl), that could be produced with the application of the carbon dioxide enhanced oil recovery $\left(\mathrm{CO}_{2}-\mathrm{EOR}\right)$ process and $(B)$ masses of associated subsurface carbon dioxide $\left(\mathrm{CO}_{2}\right)$, in millions of metric tons $(\mathrm{Mt})$, that could be stored (retained) with the application of the $\mathrm{CO}_{2}-\mathrm{EOR}$ process in existing miscible oil reservoirs underlying onshore and State waters areas of the conterminous United States. The bar graphs show mean estimates and the $P_{5^{\prime}} P_{50^{\prime}}$ and $P_{95}$ probability percentiles, which represent the 5-, 50-, and 95-percent probabilities, respectively, that the true resource is less than or equal to the value shown. Regional results are also illustrated by pie charts in figure 1 and are listed in table 2. Values are reported to only two significant figures. Resources in Alaska (Region 1), Hawaii, and federally owned offshore areas were not assessed. Petroleum region and province boundaries are from the U.S. Geological Survey's 1995 National Oil and Gas Assessment (NOGA) (Beeman and others, 1996).

The Energy Independence and Security Act of 2007 (U.S. Congress, 2007) authorized the USGS to conduct a national assessment of geologic storage resources for $\mathrm{CO}_{2}$ and requested the USGS to estimate the "potential volumes of oil and gas recoverable by injection and sequestration of industrial carbon dioxide in potential sequestration formations" (42 U.S.C. 17271(b)(4)). To accomplish this assessment, the USGS developed a national database that contained geologic and engineering parameters necessary for screening oil reservoirs for the application of $\mathrm{CO}_{2}$-EOR methods (Carolus and others, 2017) and published a probabilistic methodology that could be used to assess qualifying oil reservoirs for their technically recoverable hydrocarbon potential and estimate the $\mathrm{CO}_{2}$ remaining in the reservoir after the completion of the $\mathrm{CO}_{2}$-EOR process (Warwick and others, 2019).

The use of $\mathrm{CO}_{2}$-EOR techniques in identified hydrocarbon reservoirs can increase the national recoverable hydrocarbon resource volumes. Because some of the injected $\mathrm{CO}_{2}$ is retained in the reservoir, use of anthropogenic $\mathrm{CO}_{2}$ in the EOR process could potentially help reduce the amount of $\mathrm{CO}_{2}$ released to the atmosphere that might contribute to global warming as a greenhouse gas. The International Energy Agency (2015) estimated that oil produced by using anthropogenic $\mathrm{CO}_{2}$ in the $\mathrm{CO}_{2}$-EOR process averages about 63 percent less carbon emitted than oil produced through traditional oil production methods.

The objective of this fact sheet is to summarize the results of a USGS assessment of (1) the volumes of oil that could be technically recoverable by applying the $\mathrm{CO}_{2}$-EOR process to suitable oil reservoirs and (2) the mass of $\mathrm{CO}_{2}$ that could be stored (retained) in petroleum reservoirs within the conterminous United States and State waters areas as a result of the application of the $\mathrm{CO}_{2}$-EOR process (Warwick and others 2022a, b). The methodology used for the assessment (Warwick and others, 2019) follows the current practice in industry to maximize oil production rather than $\mathrm{CO}_{2}$ retention because, in the general absence of regulations or economic incentives, industry practice is to minimize $\mathrm{CO}_{2}$ retention in the subsurface (Jahangiri and Zhang, 2010). The assessment results are estimates of the technically recoverable oil resource that is available with the application of the $\mathrm{CO}_{2}$-EOR process. The estimates do not include economic, logistical, legal, environmental, or political constraints, such as the availability of pipelines for $\mathrm{CO}_{2}$ supply, surface ownership or use, or tax incentives for recovering the resource. 


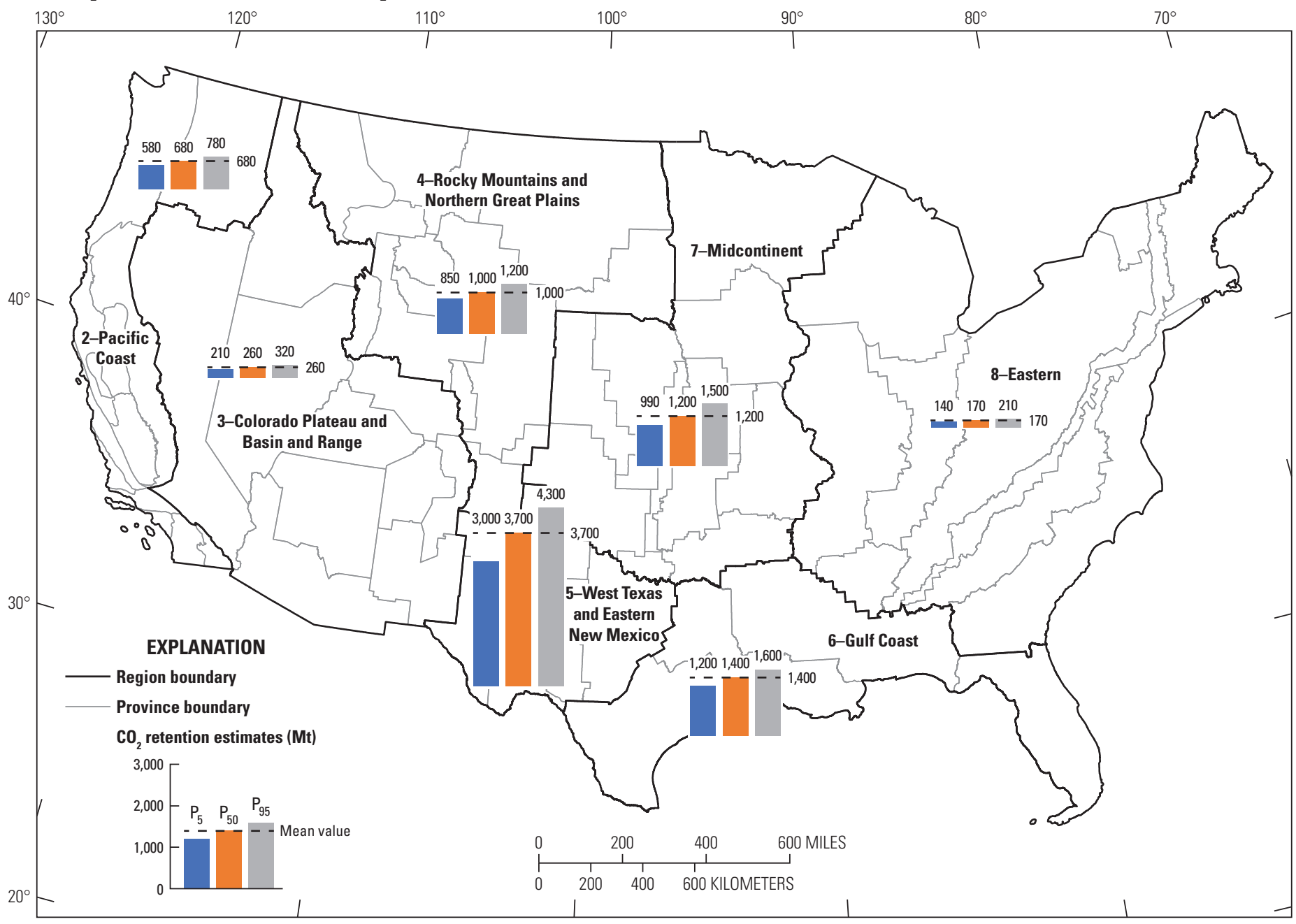

Figure 2. Continued

Table 1. Total estimated volume of oil that could be produced with carbon dioxide enhanced oil recovery $\left(\mathrm{CO}_{2}-\mathrm{EOR}\right)$ and total mass of associated carbon dioxide $\left(\mathrm{CO}_{2}\right)$ that could be stored (retained) in existing reservoirs underlying onshore and State waters areas of the conterminous United States.

[Estimates of volumes of oil that could be produced with $\mathrm{CO}_{2}$-EOR are in millions of petroleum barrels (MMbbl), and estimates of the mass of associated $\mathrm{CO}_{2}$ that could be stored (retained) are in millions of metric tons (Mt). $\mathrm{P}_{5}, \mathrm{P}_{50}$, and $\mathrm{P}_{95}$ are probability percentiles and represent the 5-, 50-, and 95-percent probabilities, respectively, that the true resource is less than or equal to the value shown. The terminology used in this fact sheet differs from that used by the petroleum industry and follows standard statistical practice (for example, Everitt and Skrondal, 2010), where percentiles, or fractiles, represent the value of a variable below which a certain proportion of observations falls. The percentiles were calculated by using the aggregation method described in U.S. Geological Survey Geologic Carbon Dioxide Storage Resources Assessment Team (2013) and in Blondes and others (2013). Percentile values do not sum to totals because the aggregation procedure used partial dependencies between assessment units. Values are reported to only two significant figures]

\begin{tabular}{lrrrr}
\multicolumn{1}{c}{ Resource type } & $\mathbf{P}_{\mathbf{5}}$ & $\mathbf{P}_{\mathbf{5 0}}$ & $\mathbf{P}_{\mathbf{9 5}}$ & Mean \\
\hline Oil produced during $\mathrm{CO}_{2}$-EOR (MMbbl) & 25,000 & 29,000 & 32,000 & 29,000 \\
$\mathrm{CO}_{2}$ retention (Mt) & 7,400 & 8,400 & 9,500 & 8,400 \\
\hline
\end{tabular}


Table 2. Estimated volume of oil that could be produced with carbon dioxide enhanced oil recovery $\left(\mathrm{CO}_{2}\right.$-EOR) and estimated mass of associated carbon dioxide $\left(\mathrm{CO}_{2}\right)$ that could be stored (retained) in existing reservoirs underlying onshore and State waters areas of the conterminous United States, aggregated by region and province.

[Estimates of volumes of oil that could be produced with $\mathrm{CO}_{2}$-EOR are in millions of petroleum barrels (MMbbl), and estimates of the mass of associated $\mathrm{CO}_{2}$ that could be stored (retained) are in millions of metric tons (Mt). $\mathrm{P}_{5}, \mathrm{P}_{50}$, and $\mathrm{P}_{95}$ are probability percentiles and represent the 5-, 50-, and 95-percent probabilities, respectively, that the true resource is less than or equal to the value shown; for more information on the percentiles, see table 1 . The $\mathrm{P}_{50}$ (median) values may be less than mean values because most output distributions are right skewed. Values are reported to only two significant figures, and mean entries may not sum to totals because of rounding. A four-digit code identifies the USGS-specific province. Resources in Alaska (Region 1), Hawaii, and federally owned offshore areas were not assessed]

\begin{tabular}{|c|c|c|c|c|c|c|c|c|c|}
\hline \multirow{2}{*}{$\begin{array}{l}\text { Province } \\
\text { number }\end{array}$} & \multirow[t]{2}{*}{ Province name } & \multicolumn{4}{|c|}{ Oil produced with $\mathrm{CO}_{2}$-EOR (MMbbl) } & \multicolumn{4}{|c|}{$\mathrm{CO}_{2}$ retention with $\mathrm{CO}_{2}-\mathrm{EOR}(\mathrm{Mt})$} \\
\hline & & $\mathbf{P}_{5}$ & $\mathbf{P}_{50}$ & $\mathbf{P}_{95}$ & Mean & $\mathbf{P}_{5}$ & $\mathbf{P}_{50}$ & $\mathbf{P}_{95}$ & Mean \\
\hline \multicolumn{10}{|c|}{ Region 2-Pacific Coast } \\
\hline 5009 & Sacramento Basin & 6.7 & 8.7 & 11 & 8.7 & 1.7 & 2.2 & 2.7 & 2.2 \\
\hline 5010 & San Joaquin Basin & 690 & 850 & 1,000 & 850 & 190 & 230 & 270 & 230 \\
\hline 5011 & Central Coastal & 5.0 & 6.5 & 8.0 & 6.5 & 1.1 & 1.5 & 1.8 & 1.5 \\
\hline 5013 & Ventura Basin. & 710 & 880 & 1,100 & 880 & 210 & 260 & 310 & 260 \\
\hline \multirow[t]{2}{*}{5014} & Los Angeles Basin & 620 & 760 & 890 & 760 & 150 & 190 & 220 & 190 \\
\hline & Aggregated total & 2,100 & 2,500 & 2,900 & 2,500 & 580 & 680 & 780 & 680 \\
\hline \multicolumn{10}{|c|}{ Region 3-Colorado Plateau and Basin and Range } \\
\hline 5020 & Uinta-Piceance Basin & 240 & 320 & 400 & 320 & 78 & 100 & 130 & 100 \\
\hline 5021 & Paradox Basin & 53 & 66 & 79 & 66 & 17 & 20 & 25 & 21 \\
\hline \multirow[t]{2}{*}{5022} & San Juan Basin & 380 & 530 & 690 & 530 & 100 & 140 & 180 & 140 \\
\hline & Aggregated total & 710 & 910 & 1,100 & 910 & 210 & 260 & 320 & 260 \\
\hline \multicolumn{10}{|c|}{ Region 4-Rocky Mountains and Northern Great Plains } \\
\hline 5028 & North-Central Montana & 60 & 73 & 87 & 73 & 16 & 19 & 23 & 19 \\
\hline 5031 & Williston Basin & 1,100 & 1,300 & 1,600 & 1,300 & 370 & 460 & 560 & 460 \\
\hline 5033 & Powder River Basin & 740 & 890 & 1,000 & 890 & 210 & 260 & 300 & 260 \\
\hline 5034 & Big Horn Basin & 330 & 400 & 480 & 400 & 90 & 110 & 130 & 110 \\
\hline 5035 & Wind River Basin & 69 & 87 & 100 & 87 & 17 & 22 & 26 & 22 \\
\hline 5036 & Wyoming Thrust Belt & 5.5 & 7.6 & 10 & 7.7 & 2.1 & 2.9 & 3.9 & 2.9 \\
\hline 5037 & Southwestern Wyoming & 40 & 49 & 58 & 49 & 12 & 14 & 17 & 14 \\
\hline 5038 & Park Basins & 0.84 & 1.2 & 1.5 & 1.2 & 0.25 & 0.35 & 0.46 & 0.35 \\
\hline 5039 & Denver Basin & 300 & 380 & 470 & 380 & 82 & 100 & 130 & 100 \\
\hline \multirow[t]{2}{*}{5040} & Las Animas Arch & 23 & 29 & 35 & 29 & 6.9 & 8.6 & 10 & 8.6 \\
\hline & Aggregated total & 2,800 & 3,200 & 3,800 & 3,300 & 850 & 1,000 & 1,200 & 1,000 \\
\hline \multicolumn{10}{|c|}{ Region 5-West Texas and Eastern New Mexico } \\
\hline 5044 & Permian Basin & 8,600 & 11,000 & 13,000 & 11,000 & 2,700 & 3,300 & 3,900 & 3,300 \\
\hline \multirow[t]{2}{*}{5045} & Bend Arch-Fort Worth Basin & 1,000 & 1,300 & 1,500 & 1,300 & 300 & 370 & 440 & 370 \\
\hline & Aggregated total & 9,800 & 12,000 & 14,000 & 12,000 & 3,000 & 3,700 & 4,300 & 3,700 \\
\hline \multicolumn{10}{|c|}{ Region 6-Gulf Coast } \\
\hline 5047 & Western Gulf & 2,900 & 3,500 & 4,100 & 3,500 & 760 & 920 & 1,100 & 930 \\
\hline 5049 & $\begin{array}{l}\text { East Texas Basin and Louisi- } \\
\text { ana-Mississippi Salt Basins }\end{array}$ & 1,500 & 1,800 & 2,100 & 1,800 & 400 & 480 & 570 & 480 \\
\hline \multirow[t]{2}{*}{5050} & Florida Peninsula & 3.5 & 4.7 & 5.9 & 4.7 & 1.3 & 1.7 & 2.2 & 1.7 \\
\hline & Aggregated total & 4,500 & 5,300 & 6,100 & 5,300 & 1,200 & 1,400 & 1,600 & 1,400 \\
\hline
\end{tabular}


Table 2. Estimated volume of oil that could be produced with carbon dioxide enhanced oil recovery $\left(\mathrm{CO}_{2}\right.$-EOR) and estimated mass of associated carbon dioxide $\left(\mathrm{CO}_{2}\right)$ that could be stored (retained) in existing reservoirs underlying onshore and State waters areas of the conterminous United States, aggregated by region and province.-Continued

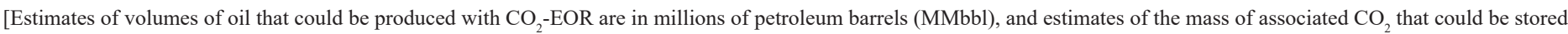

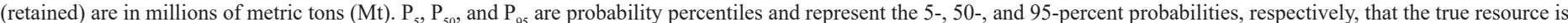

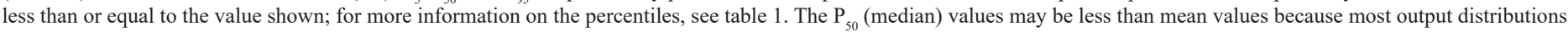

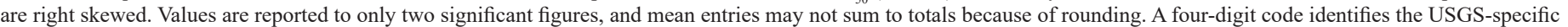
province. Resources in Alaska (Region 1), Hawaii, and federally owned offshore areas were not assessed]

\begin{tabular}{|c|c|c|c|c|c|c|c|c|c|}
\hline \multirow{2}{*}{$\begin{array}{c}\text { Province } \\
\text { number }\end{array}$} & \multirow[t]{2}{*}{ Province name } & \multicolumn{4}{|c|}{ Oil produced with $\mathrm{CO}_{2}$-EOR (MMbbl) } & \multicolumn{4}{|c|}{$\mathrm{CO}_{2}$ retention with $\mathrm{CO}_{2}-\mathrm{EOR}(\mathrm{Mt})$} \\
\hline & & $P_{5}$ & $\mathbf{P}_{50}$ & $\mathbf{P}_{95}$ & Mean & $\mathbf{P}_{5}$ & $\mathbf{P}_{50}$ & $\mathbf{P}_{95}$ & Mean \\
\hline \multicolumn{10}{|c|}{ Region 7-Midcontinent } \\
\hline 5053 & $\begin{array}{l}\text { Cambridge Arch-Central } \\
\text { Kansas Uplift }\end{array}$ & 410 & 530 & 670 & 540 & 110 & 140 & 180 & 140 \\
\hline 5055 & Nemaha Uplift & 660 & 870 & 1,100 & 870 & 190 & 250 & 320 & 250 \\
\hline 5058 & Anadarko Basin & 890 & 1,200 & 1,500 & 1,200 & 270 & 350 & 440 & 350 \\
\hline 5059 & Sedgwick Basin & 150 & 200 & 260 & 200 & 44 & 59 & 76 & 59 \\
\hline 5060 & Cherokee Platform & 550 & 740 & 960 & 750 & 150 & 200 & 260 & 200 \\
\hline 5061 & Southern Oklahoma & 500 & 690 & 910 & 690 & 140 & 200 & 260 & 200 \\
\hline \multirow[t]{2}{*}{5062} & Arkoma Basin & 48 & 64 & 83 & 65 & 14 & 19 & 25 & 19 \\
\hline & Aggregated total & 3,500 & 4,300 & 5,100 & 4,300 & 990 & 1,200 & 1,500 & 1,200 \\
\hline \multicolumn{10}{|c|}{ Region 8-Eastern } \\
\hline 5063 & Michigan Basin & 220 & 290 & 370 & 290 & 72 & 94 & 120 & 95 \\
\hline 5064 & Illinois Basin & 84 & 110 & 140 & 110 & 23 & 29 & 37 & 29 \\
\hline \multirow[t]{2}{*}{5067} & Appalachian Basin & 98 & 120 & 150 & 120 & 39 & 49 & 59 & 49 \\
\hline & Aggregated total & 420 & 520 & 640 & 530 & 140 & 170 & 210 & 170 \\
\hline
\end{tabular}




\section{References Cited}

Beeman, W.R., Obuch, R.C., and Brewton, J.D.., comps., 1996, Digital map data, text, and graphical images in support of the 1995 national assessment of United States oil and gas resources: U.S. Geological Survey Digital Data Series DDS-35, 1 CD-ROM.

Blondes, M.S., Schuenemeyer, J.H., Olea, R.A., and Drew, L.J., 2013, Aggregation of carbon dioxide sequestration storage assessment units: Stochastic Environmental Research and Risk Assessment, v. 27, no. 8, p. 1839-1859.

Carolus, M., Biglarbigi, K., Warwick, P.D., Attanasi, E.D., Freeman, P.A., and Lohr, C.D., 2017, Overview of a comprehensive resource database for the assessment of recoverable hydrocarbons produced by carbon dioxide enhanced oil recovery (ver. 1.1, June 2018): U.S. Geological Survey Techniques and Methods, book 7, chap. C16, 31 p., accessed June 12, 2018, at https://doi.org/10.3133/tm7C16.

Everitt, B.S., and Skrondal, A., 2010, The Cambridge dictionary of statistics (4th ed.): Cambridge, England, Cambridge University Press, 478 p.

International Energy Agency, 2015, Storing $\mathrm{CO}_{2}$ through enhanced oil recovery: International Energy Agency Insights Series 2015, 46 p., accessed August 11, 2021, at https://nachhaltigwirtschaften.at/ resources/iea_pdf/reports/iea_ghg_storing_co2_trough_enhanced_oil_ recovery.pdf.

Jahangiri, H.R., and Zhang, D., 2010, Optimization of carbon dioxide sequestration and enhanced oil recovery in oil reservoir: Society of Petroleum Engineers, Western North America Regional Meeting, Anaheim, Calif., May 27-29, 2010, paper SPE-133594-MS, 9 p.

U.S. Congress, 2007, Energy Independence and Security Act of 2007Public Law 110-140: U.S. Government Printing Office, 311 p., accessed March 26, 2020, at https://www.govinfo.gov/content/pkg/ PLAW-110publ140/pdf/PLAW-110publ140.pdf.
U.S. Geological Survey Geologic Carbon Dioxide Storage Resources Assessment Team, 2013, National assessment of geologic carbon dioxide storage resources - Results (ver. 1.1, September 2013): U.S. Geological Survey Circular 1386, 41 p., accessed March 26, 2020, at https://pubs.usgs.gov/circ/1386/.

Warwick, P.D., Attanasi, E.D., Blondes, M.S., Brennan, S.T., Buursink, M.L., Cahan, S.M., Doolan, C.A., Freeman, P.A., Karacan, C.Ö., Lohr, C.D., Merrill, M.D., Olea, R.A., Shelton, J.L., Slucher, E.R., and Varela, B.A., 2022a, National assessment of carbon dioxide enhanced oil recovery and associated carbon dioxide retention resources-Data: U.S. Geological Survey data release, https://doi.org/10.5066/P9AG37KI.

Warwick, P.D., Attanasi, E.D., Blondes, M.S., Brennan, S.T., Buursink, M.L., Cahan, S.M., Doolan, C.A., Freeman, P.A., Karacan, C.Ö., Lohr, C.D., Merrill, M.D., Olea, R.A., Shelton, J.L., Slucher, E.R., and Varela, B.A., 2022b, National assessment of carbon dioxide enhanced oil recovery and associated carbon dioxide retention resources - Results: U.S. Geological Survey Circular 1489, 39 p., https://doi.org/10.3133/cir1489.

Warwick, P.D., Attanasi, E.D., Olea, R.A., Blondes, M.S., Freeman, P.A., Brennan, S.T., Merrill, M.D., Verma, M.K., Karacan, C.Ö., Shelton, J.L., Lohr, C.D., Jahediesfanjani, H., and Roueché, J.N., 2019, A probabilistic assessment methodology for carbon dioxide enhanced oil recovery and associated carbon dioxide retention: U.S. Geological Survey Scientific Investigations Report 20195115, 51 p., accessed March 26, 2020, at https://doi.org/10.3133/ sir20195115.

By Peter D. Warwick, Emil D. Attanasi, Madalyn S. Blondes, Sean T. Brennan, Marc L. Buursink, Steven M. Cahan, Colin A. Doolan, Philip A. Freeman, C. Özgen Karacan, Celeste D. Lohr, Matthew D. Merrill, Ricardo A. Olea, Jenna L. Shelton, Ernie R. Slucher, and Brian A. Varela

For more information, please contact:

Program Coordinator

Energy Resources Program

U.S. Geological Survey

12201 Sunrise Valley Drive

Reston, VA 20192

Telephone: 703-648-6470

https://www.usgs.gov/energy-and-minerals/ energy-resources-program/connect

Publishing support provided by the Reston Publishing Service Center 